\title{
Multiculturalism and Cultural Identity in Art Production
}

\author{
Faeza Al-Thamari, Zahra Al-Zadjali, Badar Al-Mamari \\ Art Education Department, Sultan Qaboos University, Muscat, Oman \\ Email: faizaa@squ.edu.om
}

How to cite this paper: Al-Thamari, F., Al-Zadjali, Z., \& Al-Mamari, B. (2020). Multiculturalism and Cultural Identity in Art Production. Open Journal of Social Sciences, $8,159-173$.

https://doi.org/10.4236/jss.2020.811016

Received: October 5, 2020

Accepted: November 17, 2020

Published: November 20, 2020

Copyright (c) 2020 by author(s) and Scientific Research Publishing Inc. This work is licensed under the Creative Commons Attribution International License (CC BY 4.0).

http://creativecommons.org/licenses/by/4.0/

(c) (i) Open Access

\begin{abstract}
The progressive stage of remarkable development in the studies conducted at the fields of multiculturalism and indigenous arts has the key role for revealing the perception of cultural differences, believes and traditions. As a way for plenty of thoughtful readings has presented the value of cultural and social theories, it could also be useful ways for presenting thoughtful accepting on intercultural boundaries. Such themes are included constantly to deal with the perceptions of people discrimination, cultural diversity and social and cultural identity. The current study presents a review on the multicultural issues that are tackled mainly for verifying the salient values of cultural intersection and cultural connections with concerning indigenous arts. The article will also consider to review the influence of multiculturalism in the most applicable types of indigenous arts. It reviews, through relevant studies, the recent issues of cultural transformation, effective roles of indigenous art, and multiculturalism that are emerged in the social and cultural field. The article aims to tie the reviewed intercultural issues with the external influential factors that are assumed to impact the community fabric compressively. The present study could approve that cultural diversity causes differences in perception of cultural identity and ways of producing indigenous arts. Since most results emphasize that indigenous artists produce different artistic products at various multicultural environments with the basis of cultural background, ethnicity and identity. Instead, the study confirms that existing diverse culturally environments are essential for providing original aspects of traditional products.
\end{abstract}

\section{Keywords}

Culture, Socio-Cultural Issues, Social Identity, Social-Cultural Theories

\section{Introduction}

Experts at the social works often rely in their studies on measurable criteria that 
ensure giving precise definition of cultural status of multicultural societies out of huge numbers of intercultural studies. Multiculturalism can be broadly described as developmental context of intellectual, social, religious, moral and practices in a society, in which these have capabilities to affect profoundly a wider part of the societal composition. The view of multiculturalism along with indigenous arts emanates from the depth obvious macrocultural values of the mainstream context of a society. The most in-use methods, are treated for the concepts of intercultural artworks and indigenous arts, are the methods depending on variation in identical and residential societies (McGuire \& Schiffer, 1983), traditional cultures (Bartel, 1982), and finally cultures of multicultural and intersection inclinations (Jones, 1980). Such methods are undertaken universally for culturally distinguishing societies and provide another means for establishing the perception of multiculturalism. Some research is technically associate socio-cultural status for various values of culturalism (Blitz, 1993), cultural differences (Pauketat \& Emerson, 1991), volume (Nelson, 1981), quantity of cultural categories, and various forms of cultural identity (Cowgill, Altschul, \& Sload, 1984). Moreover, most of the signs indicate that the importance of multicultural values is related to the means that typically define the process clarifying the cultural changes, which widely depend on the variation of identity of population and different aspects of the cultural background (Braun, 1983).

Plenty of studies have addressed the issues of multiculturalism, traditional arts as a value of indigenous artwork and the cross-cultural use of demonstrating identity. Such studies determine the terms of designing perception of cultural distribution or high-value of variation, which is counted as focal contemporary social phenomenon (Blitz, 1993).

In line with the context of socio-culture, which has mainstream of multicultural and conservative societies and indigenous arts (Krishnan, 1997), such mainlines are considered to include individuals' characters into specialised researches of socio-cultural aspects for displaying strength part of literary definitions.

\section{Methodology}

The current study is carried out based on certain investigated relevant methods selected for presenting reliable information about intercultural communication across various cultures of individuals. The study comprehensively designed by all tools of the suitable research method to respond to the aim of demonstrating the basic perceptions of cross-culture and multicultural definitions. The data selected for the current study is drawn out to present the conceptual model of cross-cultural communication. Therefore, the study employed a variety of methods designed to achieve the all study objectives. The processing tools of the research method are used for the purpose of gathering the basic information and designing the conceptual framework for clarifying some suggestions of perceptions set out in the proposed model (Figure 1). In addition to, using some tools 


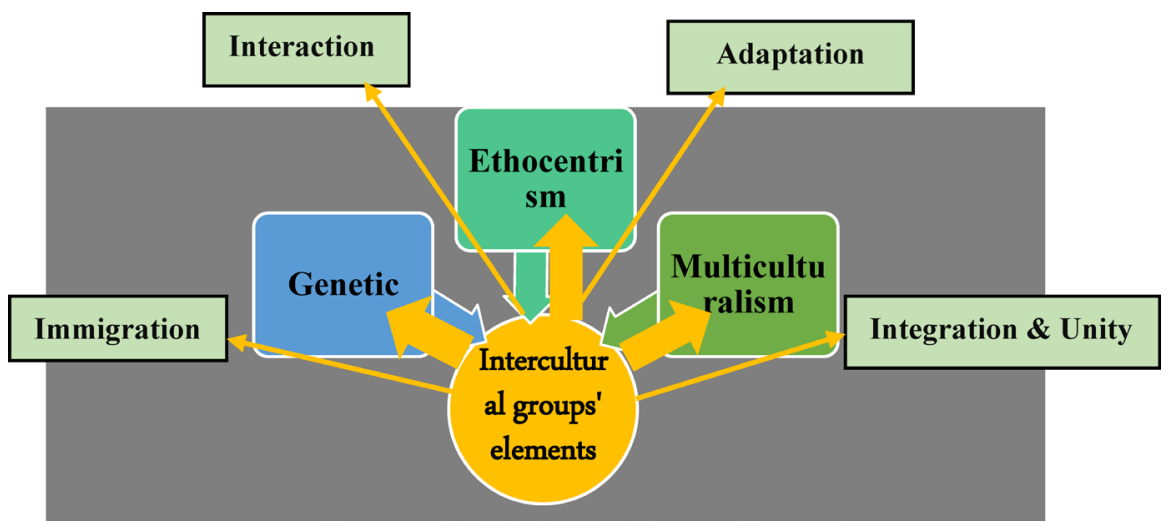

Figure 1. A model outlines three components of international groups' traits rounded in two periods for verifying four characteristics of culturalism.

for gathering information by open sources and conducting different types of fieldwork interviews. The study concentrates on analysing the data collections of previous studies done on several rural districts of Malaysia as closest samples of Asian aboriginal domestic producers. A group of folk artists, entrepreneurs, and artisans are involved intensively for enriching the reviewed process of data collection, and are employed for emphasising the salient values of multiculturalism at the indigenous arts.

\section{Generating of Intercultural Sensitivity Models for the Ideas of Current Research}

The model originated by Bennett (Bennett, 1986; Bennett, 1993) to demonstrate the indicators of cultural sensitivity from two initial stages of ethnocentric awareness of cultural diversity (denial and defence) to the further two theoretical stages (Bennett \& Bennett, 2004) (minimization) to move to the last two stages of ethnorelativism (acceptance and adaptation). Increasing levels of ethnocentrism at the Developmental Model of Intercultural Sensitivity (DMIS) elaborates less clarified perception of culture in general, cultural differences, and interaction and integrating with other cultures and your own culture. Ethnorelative levels shown in the model describes increasing indicators of one's cultural perception of differences, and increase cultural sensitivity and awareness. By other definition to DMIS given by Bhawuk and Brislin (1992) "to be effective in another culture, people must be interested in other cultures, be sensitive enough to notice cultural differences, and then also be willing to modify their behaviour as an indication of respect for the people of other cultures" (p. 416). Similar elements of such model has been derived for artisans and folk artists to increase their awareness to the cultural diversity and take benefits of work effectively interaction with diverse groups of clients' preferences.

The first ethnocentric continuum stage as described by Bennett (1983), (Table 1 ) is the Denial, in which individuals experience the diversity of culture and appreciation of cultural differences. Such individuals' perception towards cultural differences is still incomplete and under-developing due to narrow-minded 
Table 1. Developmental model of intercultural sensitivity (DMIS).

The Developmental Model of Intercultural Sensitivity (DMIS) Perceptual Experience of differences

\begin{tabular}{cccccc}
\hline Denial & Defense & Minimization & Acceptance & Adaptation & Integration \\
\hline $\begin{array}{c}\text { Failing to perceive the } \\
\text { existence or relevance } \\
\text { of culture }\end{array}$ & $\begin{array}{c}\text { Perceiving specific } \\
\text { cultural groups in } \\
\text { polarized and } \\
\text { evaluative ways }\end{array}$ & $\begin{array}{c}\text { Focusing on shared } \\
\text { human experience and } \\
\text { universal values to } \\
\text { reduce prejudice }\end{array}$ & $\begin{array}{c}\text { Attributing equal } \\
\text { human complexity to } \\
\text { different cultural } \\
\text { groups }\end{array}$ & $\begin{array}{c}\text { Generating } \\
\text { appropriate and } \\
\text { authentic alternative } \\
\text { behaviour }\end{array}$ & $\begin{array}{c}\text { Including cultural } \\
\text { context in } \\
\text { acting with contextual } \\
\text { ethnical commitment }\end{array}$ \\
\hline Ethnocentrism & & Ethno relativism
\end{tabular}

believes of multiculturalism. The experience of one's culture is stated by Bennett \& Bennett (2004) as "the only real one" that it may be demonstrated as the result of an ethnocentric orientation. The second stage in the model concentrates certain individuals who either enthusiastically approve the aspects of their culture and, in other side, intensify the characters of other cultures. By other meaning, they highly endorse their own cultures and excessively approve other cultures. The third stage of Bennett's model is Minimization stage that describes the global-view of individuals in generalising their need and global view to the social experiences of human beings (Bennett \& Bennett, 2004).

For the three stages mentioned in the model, it clarifies that all individuals are assumed to be equal and part of humanity. Thus, the assumption is that we are all equal in the desire and the literally cultural social experiences. In general, in the Minimization stage all individuals are even in their perceptions of diversity in cultural experiences, social values and beliefs.

The fourth stage is the Acceptance stage, in this stage individuals can differentiate and/or unify the ways of people experiencing social cultural differences and multiculturalism as these ways target such individuals who differentiate themselves culturally but not upraise one culture as they have great significant over another.

The stage of Adaption, individuals would be able precisely to represent the effective experiences of other cultural groups and their members via applicable and accurate ways as clearly they were raised in that culture. The last stage is Integration stage in which individuals are able to observe through global-view ascriptions of different cultures and considerate themselves culturally as either isolated or as constructive, where interactions with multiple cultures as a positive experience (Bennett, 1993).

The Bennett's model has revised throughout further years by Hammer (2012) to modify the DMIS framework and collaborate the results of his revisions as Intercultural Development Continuum (IDC) to be introduced as modified framework of a new model (Hammer, 2012) (Figure 2). In this revision of modified framework contains emphasizing on the Minimization stage as conceptualized stage.

In the developmental model, the levels of ethnocentrism are not considered rather it concentrates on the transformational stage in between Monocultural to 


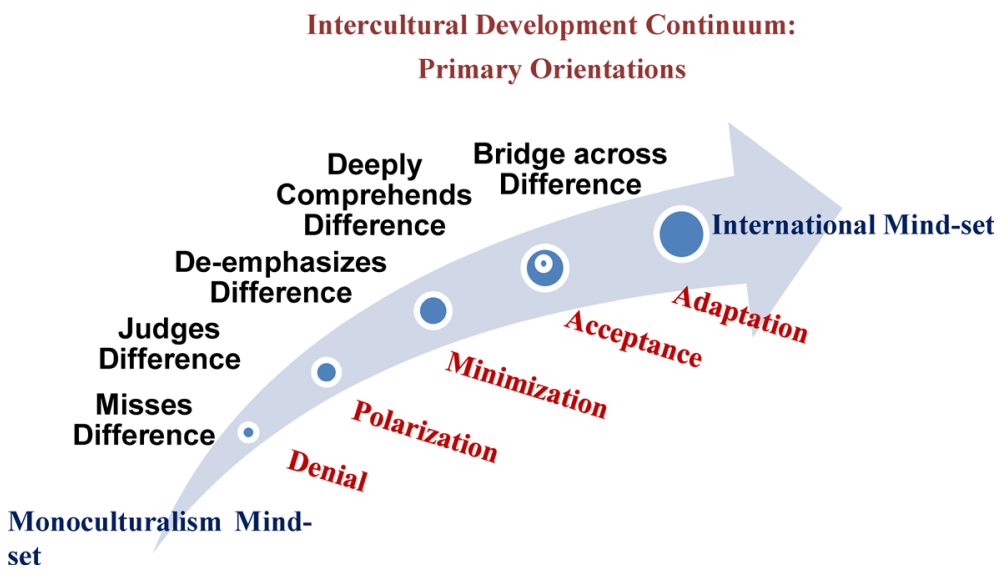

Figure 2. Modified from the Developmental Model of Intercultural Sensitivity (DMIS). Bennett (1986).

Intercultural Mindsets (Hammer, 2012). The Denial, Minimization and Adaptation stages are stated by Hammer (2012) as "primary orientation of intercultural competence"; while, the Integration stage in Bennett's original model DMIS, is assumed a form of individual's cultural identity rather than being a segment of development of intercultural competence, in which no longer could be measured separately.

It is obviously noticed that cultural disintegration has observed and added to the DMIS as in later stage for cultural competence orientations. It is approval of that some individuals in their interaction could still be disconnected and literally are not involved with any particular cultural groups. However, the far interpretation extracted from the model asserts, based on IDI $^{\circledR}$ assessment results collected, existing three actual types of orientation scores such as, a Perceived Orientation (PO), a Developmental Orientation (DO), and an Orientation Gap (OG) score; but results confirm that disconnection and unity are possibly occurred in a way of achieving parity.

\section{Overview of Intercultural and Cross-Cultural Issues}

In this work-paper the main structural definition of Intercultural Communication has argued for an understanding of culture that was dynamic and interconnected with other cultures. In this, we look at barriers to intercultural communication by presenting some cultural terms such as ethnocentrism, stereotypes, prejudice, language as a tool of communication, and a description of Bennett's (1993).

Long ago, the deep-rooted of intercultural-community inherited continually to meet with huge expansionism occurred in the late nineteenth century (David \& Kramer, 2001).

The constructive context of intercultural interpretation relies directly on inferential reasoning (Porr, 1999), most of research methods characterize socio-culture and cross-culture with strategical view of research instead of "self-contained discipline" (Krause, 1999); however, sometime as a tool assigned for developing middle-range theory (Kosso, 1991). Based on that, the chief aim in most socio-cultural 
data accomplished in a large amount of previous studies indicates that these studies endeavour to construct stronger evidences or inferences into available cultural materials rather than present the common-sense explanations of material culture patterning (Arnold III, 1998). Most of interpretive models in this study are structured and/or generated intensively within the view of multiculturalism throughout some socio-cultural studies (David, 1992). Yet, the several of themes presented to debate the culture and artefact affairs such as culture and the technology of art possessing the ability in restrict technological study of material culture (David, 1992).

Interestingly, the models in such study reflect somehow the various values of certain elites of community in which individuals are affiliated. In such values the ways in which people live their life and interact with others are shown and clearly distinguished as they are the things people take for granted. The significance of selected models in which could help here is enabling for establishing a solid understanding about the belief of that, individuals' ways of doing things may not be the same as everyone else's.

\subsection{Culturalism and Cross-Cultural Issues}

Generally, Ethnocentrism has grabbed lots of attentions and defined as a belief in the centrality of one's own culture. It often involves judging aspects of another culture by the standards of one's own.

Bennett (1993) defines ethnocentrism as "assuming that the worldview of one's own culture is central to all reality". Said (1978) has described the ways in which the West has polarised East and West so that the West possesses positive characteristics (strength, activity, reliability) whereas the East is depicted as having opposing characteristics (fragility, passivity, wily unreliability). Bennett (1993) has proposed a developmental sequence towards intercultural sensitivity. His model outlines the stages which people go through when faced with the difficulties of intercultural contact. He refers to the first three stages as the ethnocentric stages of denial, defence and minimization.

With regards to the first division of culture and artefact effectiveness, Berns added that artefacts from the perspective of ethno-archaeology has generally designed with intercultural questions made almost by socialists; whereas, the two art elements such as art history and anthropology are counted effective components in the view of material culture (Berns, 1993). It is worthy to note that, the structure of cross-cultural research is often characterized through both theoretical and regional differences. However, the distinct aspect of intercultural research indicates that the differences explicitly are about to be parallel when it is based on the form of dispersed traditional regions and spread broadly over the realm of material cultural research.

\subsection{A Cross-Cultural Approach, the Way of Development to Multicultural Correlations}

A cross-cultural approach to language communication attempts to make explicit 
linkages between an individual's development and the social-material conditions of his or her everyday practice e.g. (Chaiklin, 2001; Engeström, 1999) in second language research (Lantolf, 2000; Swain \& Lapkin, 2000; Thorne, 2000). Higher order cognitive functions, including intentional memory, planning, voluntary attention, interpretive strategies, and forms of logic and rationality, develop out of participation in social practices such as schooling, interaction with care givers, the learning and use of semiotic systems such as spoken languages, textual and digital literacies, visual arts, music, exposure to folk and traditionally "cognitive norms" concepts (Figure 3), context-contingent behavioural norms, and spatial fields such as the social and functional divisions of built structures and visual artistic expression. All of these (and this is but a partial list) are uniquely human social-semiotic systems e.g. (Halliday, 1995) that evolve over time and continue to transform from generation to generation. To put this into modern parlance, (Vygotsky, 1978, 1986) argued that situated social interaction connected to practical activity in the material world is the source of the development of culture (Figure 4). In turn, cultural-societal structures provide affordances and constraints

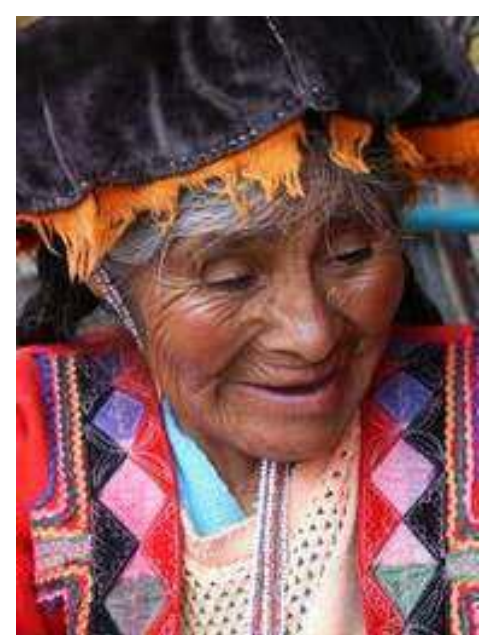

Figure 3. A tribal woman with traditional cloth from Malaysia, Ipoh.

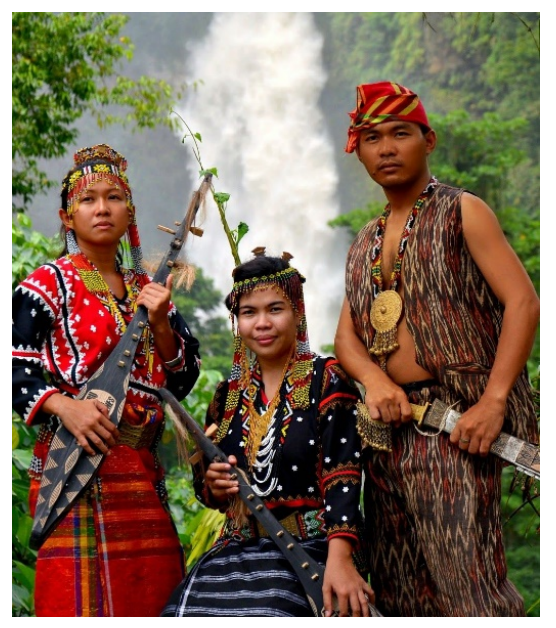

Figure 4. The T’boli women are holding the plucked lute, Philippine. 
that shape the development of specific forms of consciousness. This dialectical approach to the relation between intercultural and communication forms the conceptual basis of this research and continuously turned into today to be at the core of related sociological and psychological inquiry e.g. for theories of structuration, see (Archer, 1995; Bourdieu, 1977; Giddens, 1984; Sawyer, 2002) for an application of the social realist approach to telecollaborative foreign language learning, see (Belz, 2001).

Several of studies centralized on the issues of intercultural endeavour to arrange a degree of fluidity in the consistent of cultural interaction, in addition to manage various stages of cultural variation including specialist ways of material culture, forming, and the way of cultural integration, among the current viewpoints available for investigation the notions of cultural interaction in relating to the concepts tradition and the cultural identity (Costin, 2000). Predictably, the observation conducted on such views has proved that existing intersectional cultures might assist to vary and multiple the volume of structured material cultures across several communities (LaViolette, 2000). However, traditional artefacts as a mean of cultural structures have obtained adequate attention by researchers besides the types of cultural transformations at the modern societies.

\section{Analyses and Findings}

\section{Intersectional Cultures and an Artifact-Culture of Use}

In most intercultural and ethno-cultural studies the lifestyle of community is symbolized a focal element, which also includes all types of population norms values such as individuals' traits, social behaviours, diversity and inclusion and so on. Thus, generally, in a permanent effort to find a common definition of style that accomplish with what has been mentioned in some studies, lifestyle is defined and described as "a way of doings" (Hegmon, 1992), by other meaning, culturally lifestyle has been also recognized as the means by which individuals communicate on basis of their own social identity (Wiessner, 1983). Yet, in the countries of Southeast Asia such Malaysia and other pacific countries style of life is multifocal and its meaning is often understood from different vantages (Figure 5). Therefore, the findings of this study by observed concentration on one close group of folk culturally people has introduced their own life style mainly as symbolic communication of women's social identity to verify in particular their social identity (Gosselain, 1992) (Figure 6). The data harvested from some participant reviewers indicates that most identically producer women signify their activities through distinctive form of individual lifestyle which in most cases confirm on their incorporation with the society socially, culturally as well as political alliances.

With analysing data from intercultural perspective it has been described that the purpose of communication by an actor with their environment and surrounding, or from other hand with the receivers is to persuade, influence, and manipulate the receivers who develop strategies to resist their culture manipulation (Cronk, 1999). 


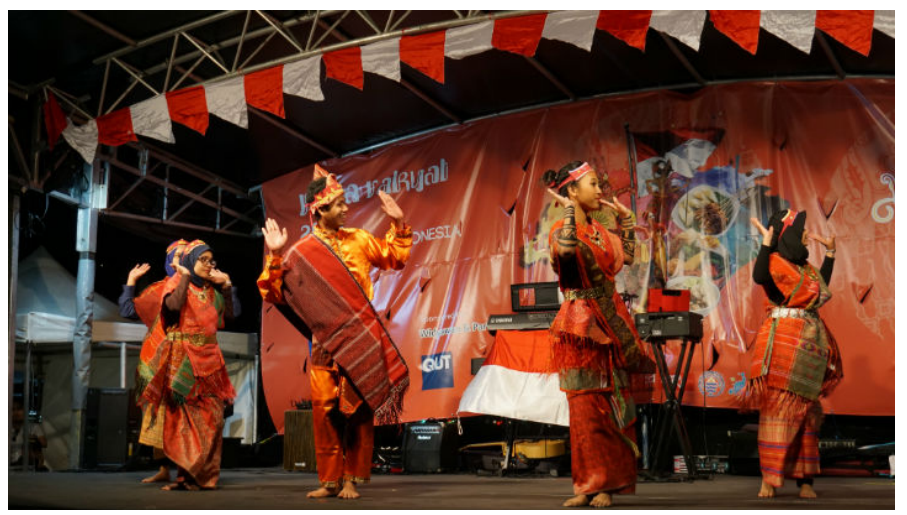

Figure 5. Traditional dance shows Indonesian culture and folk arts.

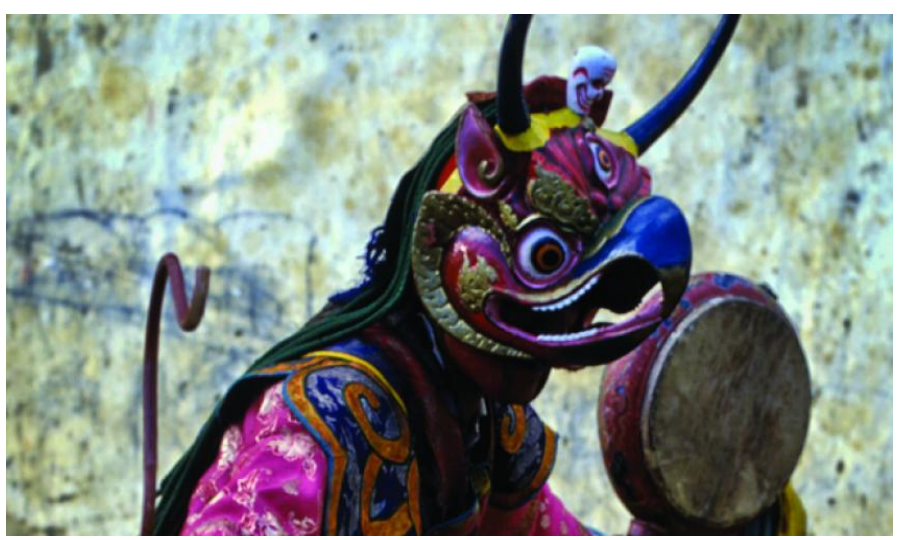

Figure 6. Safeguarding at multicultural carnival reflecting the traditional beliefs and cultural diversity.

According to the rule followed in theoretical approaches of descriptive data, a sample of individual identity of focus group such Mir. Meor Amirul Din Bin Aris confirms that "an individual's personality is emphasized from through designing and managing culturally their lifestyle" (Grudin, 1990). This meets with what many of researchers stated that individuals typically are reflected through their handmade artefacts as positive image of themselves, and this would give the impression of affiliation and unite an individual in their small community into another single group of the such community (Wiessner, 1983). Therefore, in such sense, stylistic similarity observed within group interviewers indicate that presence traits of similarities or converges are more important in order to reflect the social and cultural boundaries and the intellectual differences (Wobst, 1977).

Interestingly, most specialists have been met in the field ethno-cultural communication are either engaged with producing new characters of cultural behaviours, or occupied in artefactual and cultural centres. As it has observed that cultural makers pay often attention to get aware about the factors might effect and influentially create their distinctive cultural background (Figure 7), such intellectual orientation led plenty of ethno-culturalisms to investigate the influential factors affecting on peoples' cultural background and other types of cultural unity (Bourges, 1996). It is also markedly noted that most recent studies are 


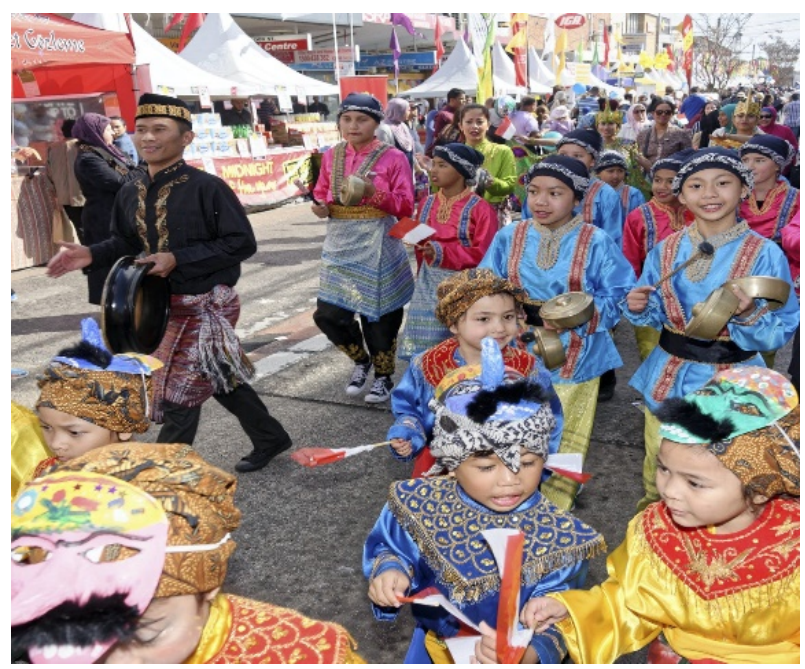

Figure 7. Multiculturalism shows the cultural diversity in one society of Asian countries.

drawn to study various issues of cross-cultural issues and numerous aspects manifold that contain generally folk cultures' need, people cultural preferences, and marketing rules (Aronson, Skibo, \& Stark, 1994). Nevertheless, during pursuing some of impactful cultural activities it was evident that some of cross-cultural producers are motivated to make various culturally feedback based on different types of cultural effective preference; as well in some other types of cultural differentiation we can observe the differences among people maintaining of own culture from the perspective of social and ethnic identities (Arnold \& Nieves, 1992). In other side, in what regard to the cultural distinctively receivers, it is need to be undergone with closer analyses research investigates the factors that might affect them as well (Bourges, 1996).

In the data collected from different sites of Malaysia as a main focus-study site, most interests are directed data to concentrates on categorizing the factors effect on cultural differentiation more than analysing the cultural producers' personal skills and associate it with the diversity and cultural unity design of community. In other hand, it was noted that increasing the cultural diversity numbers leads to increase the quantity of cultural values (Kramer, 1985). Besides, the variability that occurs due to transformations in different cultural status (Arnold \& Nieves, 1992). Continuously, the variables in difference of cultural index are measured to identify the homogeneity and uniquely aspect in the utilitarian values of cross-cultures or other type of cultural producers, as these odds might affect entirely on the image of cultural background and shapes a quality of solid cultural differences (Kvamme, Stark, \& Longacre, 1996), as among conducted assays these are have focused on the differences among the amount of diversity of culture resulting from independent folk artists and cultural producers who are more specialists than those who are dependent specialists and attached to other cultural institutions, as those last group in present days are less to contribute positively in the terms of cultural diversity comparing to the independent groups of folk cultural producers. 


\section{Discussion}

In the context of the gradual evolution of design as one of significant intercultural issue, analytical patterns are found to be more workable for stylistic analysis that has been specialized for prehistoric cultural traits; however, studies, which concentrate on prehistoric cultural issues, are more motivated to demonstrate the aspects of "cultural" and temporal variability; thus, ethno-cultural values became a major source bases for cross-cultural studies. By other meaning, culturalism is more aggressive towards ethno-cultural fieldwork when it is in need to explore the correlations between cultural material and none cultural material elements of a society (Longacre, 1974). Yet, ethno-cultural quickly became an established subfield of cross-cultural and cultural diversity, which benefits for enriching our understanding of the cultural connections between cultural material and human behaviour. Hence, in Table 2 the attempt to obtain the constituents of Intercultural Groups of a Community is shown by the elements of Genetic, Ethno-culturalism, and Multiculturalism and its offsets of Immigration, Intersection, Adaption, and Integration \& Unity social; those elements are statistically considered effective elements of groups of art producers. The components of Genetic, Ethno-culturalism, and Multiculturalism are essential factors in the variations of multicultural human behaviours enlightened through analyses among different groups of art producers. Results also show that variation in techniques has been taken into account for illuminating some of the variability in the vessels tested in the model (e.g. the vessels tested by group elements such as, Genetic, Ethnocentrism, and Multiculturalism). It shows that when the techniques were applied by certain groups of art producers there was a significant difference among the shapes conducted for different market segments. Differentiations are appeared through the applicable methods that a potter has employed them in this products as rich methods of producing vessels that are compatible with the criteria set out for measuring particular shapes of indigenous potteries. There is difference in distinguishing between the kind of potteries produced based on the current marketing order and the measurements taken by potters within certain techniques during fabrication. In conclusion of the results there are indicators that plenty of multicultural and cross-cultural researches done in different scopes of pottery have taken into account the factors influencing this production based on variation of the variability and standardization that are related to the concept applied on conventional pottery products. However,

Table 2. Indicates the three main components of IGE runs by PLS for verifying the values of immigration, intersection, adaption, and integration \&unity.

\begin{tabular}{cccc}
\hline \multicolumn{4}{c}{ Intercultural Groups of a Community (IGC) } \\
\hline Genetic & 0.2 & Immigration & 67 \\
Ethno-culturalism & 0.5 & Intersection & 34 \\
Multiculturalism & 0.4 & Adaption & 49 \\
& & Integration \& Unity & 53 \\
\hline
\end{tabular}


based on the coefficient of variation more standard methods are suggested to be utilized for assessing variability in comparisons among potteries that can be showing the levels of significance.

\section{Acknowledgements}

We gratefully would thank the team of folk cultural and artefacts' producers we met during conducting the field-work; in particular, Miss Yong for her invitation to Hayat Workshop in Kuala Kangsar, Mr Norazam Bin Shuib and $\mathrm{Mr}$ Mohd Fauzi Safian our interviewers in Darul Rizwan in Perak, and special thanks to Mr Shafiee Shariff Abdullah for the invitation to the fineness Artistry cultural craftsmanship of Roshfin in Selangor. I also present special grateful to the National library in Kuala Lumpur for their gently assistance and good manners guided me to access to valuable information. Last but not least my great appreciation for the editing manner provided by the respective journal upon the first draft of this article.

\section{Conflicts of Interest}

The authors declare no conflicts of interest regarding the publication of this paper.

\section{References}

Archer, M. (1995). Realist Social Theory: The Morphogenetic Approach (p. 354). Cambridge: Cambridge University Press. https://doi.org/10.1017/CBO9780511557675

Arnold III, P. (1998). Ceramic Ethnoarchaeology: Caught between "Coming of Age" and "Showing Its Age". Reviews in Anthropology, 27, 17-32. https://doi.org/10.1080/00988157.1998.9978187

Arnold, D., \& Nieves, A. L. (1992). Factors Affecting Ceramic Standardization. In G. J. Bey III, \& C. A. Pool (Eds.), Ceramic Production and Distribution: An Integrated Approach (pp. 93-113). Boulder, CO: Westview Press.

Aronson, M., Skibo, J., \& Stark, M. (1994). Production and Use Technologies in Kalinga Pottery. In W. A. Longacre, \& J. M. Skibo (Eds.), Kalinga Ethnoarchaeology (pp. 83-112). Washington DC: Smithsonian Institution Press.

Bartel, B. (1982). A Historical Review of Ethnological and Archaeological Analyses of Mortuary Practice. Journal of Anthropological Archaeology, 1, 32-58. https://doi.org/10.1016/0278-4165(82)90007-1

Belz, J. A. (2001). Institutional and Individual Dimensions of Transatlantic Group Work in Network-Based Language Teaching. Cambridge: Cambridge University Press (pp. 213-231). http://hdl.handle.net/1805/2660 https://doi.org/10.1017/S0958344001000726a

Bennett, J. M., \& Bennett, M. J. (2004). Developing Intercultural Sensitivity: An Integrative Approach to Global and Domestic Diversity. In D. R. Landis (Eds.), Handbook of Intercultural Training (p. 515). Thousand Oaks: SAGE. https://doi.org/10.4135/9781452231129.n6

Bennett, M. (1993). Towards Ethnorelativism: A Developmental Model of Intercultural Sensitivity. In R. M. Paige (Ed.), Education for the Intercultural Experience pp. 21-71). 
Yarmouth, ME: Intercultural Press.

Bennett, M. J. (1986). A Developmental Approach to Training for Intercultural Sensitivity. International Journal of Intercultural Relations, 10, 179-196. https://doi.org/10.1016/0147-1767(86)90005-2

Berns, M. (1993). Art, History, and Gender: Women and Clay in West Africa. African Archaeological Review, 11, 129-148. https://doi.org/10.1007/BF01118145

Bhawuk, D. P. S., \& Brislin, R. (1992). The Measurement of Intercultural Sensitivity Using the Concepts of Individualism and Collectivism. International Journal of Intercultural Relations, 16, 413-436. https://doi.org/10.1016/0147-1767(92)90031-O

Blitz, J. (1993). Big Pots for Big Shots: Feasting and Storage in a Mississippian Community. American Antiquity, 58, 80-96. https://doi.org/10.2307/281455

Bourdieu, B. (1977). Cultural Reproduction and Social Reproduction. In J. Karabel, \& A. H. Halsey (Eds.), Power and Ideology in Education (pp. 487-511). New York: Oxford University Press.

Bourges, C. (1996). Ceramic Ethnoarchaeology and Historical Process: The Case of Grea, North Cameroon: Archaeology (pp. 120-156). Calgary: University of Calgary.

Braun, D. (1983). Pots as Tools. In J. A. Moore, \& A. S. Keene (Eds.), Archaeological Hammers and Theories (pp. 107-134). New York: Academic Press. https://doi.org/10.1016/B978-0-12-505980-0.50012-4

Chaiklin, S. (2001). The Institutionalization of Cultural-Historical Psychology as a Multinational Practice. In S. Chaiklin (Ed.), The Theory and Practice of Cultural-Historical Psychology (pp. 15-34) Aarhus, Denmark: Aarhus University Press.

Costin, C. (2000). The Use of Ethnoarchaeology for the Archaeological Study of Ceramic Production. Journal of Archaeological Method and Theory, 7, 377-403. https://doi.org/10.1023/A:1026523023550

Cowgill, G., Altschul, J., \& Sload, R. (1984). Spatial Analysis of Teotihuacan: A Mesoamerican Metropolis. In H. J. Hietala (Ed.), Intrasite Spatial Analysis in Archaeology (pp. 154-195). Cambridge: Cambridge University Press.

Cronk, L. (1999). That Complex Whole: Culture and the Evolution of Human Behavior. Boulder, CO: Westview Press.

David, N. (1992). Integrating Ethnoarchaeology: A Subtle Realist Perspective. Journal of Anthropological Archaeology, 11, 330-359.

https://doi.org/10.1016/0278-4165(92)90012-Z

David, N., \& Kramer, C. (2001). Ethnoarchaeology in Action. Cambridge: Cambridge University Press. https://doi.org/10.1017/CBO9781316036488

Engeström, Y. (1999). Expansive Visiblization of Work: An Activity-Theoretical Perspective. Computer Supported Cooperative Work, 8, 63-93. https://doi.org/10.1023/A:1008648532192

Giddens, A. (1984). The Constitution of Society: Outline of the Theory of Structuration (p. 402). Berkeley: University of California Press.

Gosselain, O. (1992). Bonfire of the Enquiries. Pottery Firing Temperatures in Archaeology: What for? Journal of Archaeological Science, 19, 243-259.

https://doi.org/10.1016/0305-4403(92)90014-T

Grudin, J. (1990). The Computer Reaches Out: The Historical Continuity of Interface Design. In J. C. Chew, \& J. Whiteside (Eds.), Proceedings of the SIGCHI Conference on Human Factors in Computing Systems (pp. 261-268). New York: ACM Press. https://doi.org/10.1145/97243.97284 
Halliday, M. A. K. (1995). On Language in Relation to the Evolution of Human Consciousness. Of Thoughts and Words, 45-84.

https://doi.org/10.1142/9781908979681_0008

Hammer, M. R. (2012). The Intercultural Development Inventory: A New Frontier in Assessment and Development of Intercultural Competence. In M. Vande Berg, R. M. Paige, \& K. H. Lou (Eds.), Student Learning Abroad, What Our Students Are Learning, what They're Not, and What We Can Do about It (pp. 115-136). Sterling, VA: Stylus.

Hegmon, M. (1992). Archaeological Research on Style. Annual Review of Anthropology, 21, 517-536. https://doi.org/10.1146/annurev.an.21.100192.002505

Jones, A. (1980). Wealth of a Nation to Be: The American Colonies on the Eve of the Revolution (pp.145-356). New York: Columbia University Press.

Kosso, P. (1991). Method in Archaeology: Middle-Range Theory as Hermeneutics. American Antiquity, 56, 621-627. https://doi.org/10.2307/281540

Kramer, C. (1985). Ceramic Ethnoarchaeology. Annual Review of Anthropology, 14, 77-102. http://www.jstor.org/stable/2155590 https://doi.org/10.1146/annurev.an.14.100185.000453

Krause, R. (1999). Review of "Pottery Ethnoarchaeology in the Central Maya Highlands" by Michael Deal. American Antiquity, 64, 559-560.

Krishnan, K. (1997). Scientific Analysis of Pottery and Their Cultural Implications. In P. C. Pant, \& V. Jayaswal (Eds.), Ancient Ceramics: Historical Enquiries and Scientific Approaches (pp. 177-196). Delhi, India: Agam Kala Prakashan.

Kvamme, K., Stark, M., \& Longacre, W. A. (1996). Alternative Procedures for Assessing Standardization in Ceramic Assemblages. American Antiquity, 61, 116-126. https://doi.org/10.2307/282306

Lantolf, J. P. (2002). Second Language Learning as a Mediated Process. Language Teaching, Cambridge, 33, 79-96. https://doi.org/10.1017/S0261444800015329

LaViolette, A. (2000). Ethno-Archaeology in Jenné, Mali: Craft and Status among Smiths, Potters and Masons. Oxford, UK: Archaeopress.

Longacre, W. (1974). Kalinga Pottery Making: The Evolution of a Research Design. In M. J. Leaf (Ed.), Frontiers of Anthropology: An Introduction to Anthropological Thinking (pp. 51-67). New York: Van Nostrand.

McGuire, R., \& Schiffer, M. (1983). A Theory of Architectural Design. Journal of Anthropological Archaeology, 2, 277-303. https://doi.org/10.1016/0278-4165(83)90002-8

Nelson, B. (1981). Ethnoarchaeology and Paleodemography: A Test of Turner and Lofgren's Hypothesis. Journal of Anthropological Research, 37, 107-129. https://doi.org/10.1086/jar.37.2.3629704

Pauketat, T., \& Emerson, T. (1991). The Ideology of Authority and the Power of the Pot. American Anthropologist, 93, 919-941. https://doi.org/10.1525/aa.1991.93.4.02a00080

Porr, M. (1999). Archaeology, Analogy. Material Culture, Society: An Exploration. In L. R. Owen, \& M. Porr (Eds.), Ethno-Analogy and the Reconstruction of Prehistoric Artefact Use and Production (pp. 3-15). Tübingen: Geschichtliche Material hefte.

Said, E. (1978). Overcoming Orientalism (pp. 17-19). New York: Pantheon Books.

Sawyer, R. K. (2002). A Discourse on Discourse: An Archeological History of an Intellectual Concept. Cultural Studies, Taylor \& Francis, 16, 433-456.

https://doi.org/10.1080/09502380210128324

Swain, M., \& Lapkin, S. (2000). Task-Based Second Language Learning: The Uses of the First Language. Language teaching Research, Sage Journal, 4, 251-274. 
https://doi.org/10.1191/136216800125087

Thorne, A. (2000). Personal Memory Telling and Personality Development. Personality and Social Psychology Review, Sage Journal, 4, 45-56. https://doi.org/10.1207/S15327957PSPR0401_5

Vygotsky, L. S. (1978). Socio-Cultural Theory, Mind in Society. http://etec.ctlt.ubc.ca/510wiki/Sociocultural-Constructivist

Vygotsky, L. S. (1986). Thought and Language (p. 287, Vol. 29). London, Cambridge: MIT Press.

Wiessner, P. (1983). Style and Social Information in Kalahari San Projectile Points. American Antiquity, 48, 253-276. https://doi.org/10.2307/280450

Wobst, H. (1977). Stylistic Behavior and Information Exchange. In C. E. Cleland (Ed.), For the Director: Research Essays in Honor of James B. Griffin (pp. 317-342). Ann Arbor, MI: University of Michigan Press. 